(С Пашкова Ю.П., Палагнюк Г.О., Матохнюк М.О.

УДК: 004.9:371.3:378.14- 057.81:61

DOI https://doi.org/10.31718/mep.2021.25.1-2.11

\title{
ДОСВІД ВПРОВАДЖЕННЯ ІНФОРМАЦІЙНИХ ТЕХНОЛОГІЙ В ПРОЦЕСІ ВИВЧЕННЯ КЛІНІЧНОЇ ДИСЦИПЛІНИ У ВИЩОМУ МЕДИЧНОМУ НАВЧАЛЬНОМУ ЗАКЛАДІ*
}

Пашкова Ю.П., Палагнюк Г.О., Матохнюк М.О.

Вінницький національний медичний університет ім. М.І. Пирогова, м. Вінниця, Україна

\begin{abstract}
Представлена стаття дає можливість розглянути результати впровадження технологій дистанційного навчання у навчальний процес студентів Вінницького національного медичного університету імені М.I. Пирогова опановуючи навчальну дисципліну «Внутрішня медицина». На сьогоднішній день стрімко зростає кількість інформації, яка так необхідна для отримання, розуміння і засвоєння знань. Враховуючи сучасний темп розвитку освіти, на сьогодні досить актуальним $\epsilon$ пошук інноваційних форм якісної організації навчального процесу. Саме це $і$ призвело до впровадження інформаційних технологій в освіту і формування окремого виду навчання - дистанційного. Нині в Україні на всіх рівнях освіти широкого розвитку набуває дистанційна форма навчання, що надає можливість індивідуалізувати процес набуття знань, умінь, навичок і способів пізнавальної діяльності людини, який відбувається, в основному, за опосередкованої взаємодії віддалених один від одного учасників навчального процесу у спеціалізованому середовищі, що функціонує на базі сучасних інформаційно-комунікаційних технологій.

Ключові слова: дистанційне навчання, медична освіта.
\end{abstract}

Ступінь інформатизації суспільства сьогодні - це один із основних критеріїв оцінки рівня розвитку держави в цілому, її наукової, економічної політичної та військової потужності. Формування високого рівня інформаційної культури майбутніх фахівців - важливе завдання сучасної вищої школи, яка покликана готувати випускників до професійної діяльності в інформаційному суспільстві [1]. Інформаційні технології в галузі охорони здоров'я - надзвичайно важлива складова, яка повинна забезпечити високоефективну, безпечну і звичайно надійну медичну допомогу. Сьогодні інформаційні технології використовуються на всіх етапах розвитку охорони здоров'я, тому важливе їх використання з етапу здобуття медичної освіти студентом - медиком. В час XXI століття в усіх сфрерах сучасного життя зростає потреба у конкурентоспроможних, кваліфрікованих фрахівцях, обізнаних у широкому колі питань, здатних іти в ногу з прогресом. В результаті цього, стоїть вагоме питання про оволодіння навиками та подальшою компетентністю в напрямку володіння, опрацювання та подачі матеріалу з різних інформаційних джерел. Враховуючи широкомасштабність розвитку та впровадження сучасних медичних технологій важливе місце у навчанні здобувачів медичної освіти посідає вміння використовувати новітні інформаційні технології. Знання основ комп'ютерних технологій потрібне лікареві не менше, ніж економісту чи інженеру. Реалізацію та розвиток відповідної компетентності у майбутніх медиків можна досягти шляхом розробки та удосконалення певного методичного забезпечення з використанням засобів інформатизації навчального процесу. Це в свою чергу підвищить ефективність та якість навчання здобувача освіти у вищому медичному навчальному закладі [2].

Дистанційне навчання не лише активно використовується в сучасному світі, але і продовжує стрімко розвиватись. Виклики сьогодення з якими ми зіштовхнулися щодо попередження поширення коронавірусної інфекції COVID-19, надзвичайно актуалізують цю форму навчання та її вдосконалення у вищій медичній освіті. В умовах запровадження загальнонаціонального карантину відповідно до постанови Кабінету Міністрів України від 11 березня 2020 року №211 «Про запобігання поширенню на території України коронавірусу COVID-19», а також на основі рекомендацій MOH України, національні заклади освіти, зокрема у сфері вищої медичної освіти, перейшли на дистанційну форму навчання [3]. Це у свою чергу активізує нагальність розвитку цифрових компетенцій серед студентів, а також фрормування готовності викладацького складу здійснювати професійну діяльність в умовах дистанційного навчання.

Перед сучасним суспільством стоїть одна з найважливіших задач, яка спрямована на створення характерно нової і перспективної системи освіти, яка змогла б підготувати населення нашої планети до життя в нових умовах цивілізації. Без наявності маси висококваліфрікованих фахівців, здатних якісно виконувати необхідні роботи в самих різних сфрерах життя суспільства, нормальне функціонування такого складного механізму, як сучасна держава просто неможливо.

Дистанційне навчання являє собою високотехнологічний продукт, що використовує ідею безперервного навчання студентів, чим і пояснюється його активне поширення у всьому світі. Саме тому дистанційну освіту часто називають найперспективнішим напрямом розвитку освіти в цілому, особливою педагогічною технологією XXI ст., що базується на відкритому навчанні з використанням сучасних телекомунікацій для спілкування: «студент - викладач», «студент - студент», «студент - інформація» на теренах інформаційного простора. Головна особа дистанційного навчання - студент [4].

*Цитування при атестації кадрів: Пашкова Ю.П., Палагнюк Г.О., Матохнюк М.О. Досвід впровадження інформаційних технологій в процесі вивчення клінічної дисципліни у вищому медичному навчальному закладі // Проблеми екології і медицини. - 2021. - Т. 25, № 1-2. - C. 46-49. 
Навчання у середовищі Інтернет із студентами вищого медичного навчального закладу характеризується низкою переваг у порівнянні з традиційним підвищення самостійності студентів, відповідальність за власне навчання, розширення меж навчання, економія власного часу. Водночас Інтернет - простір характеризується виразною специфікою, що може скласти потенційні загрози для успішності навчання в ньому - формування залежностей, порушення ідентичності, проблеми із захистом інформації, погіршення якості спілкування, розвиток девіацій та специфічної психопатології [5].

Дистанційне навчання на сьогодні $€$ одним із ключових напрямів освітньої системи України. За останні роки відбувається активне науково-теоретичне осмислення дистанційних форм навчання, науковий обіг поповнюється новою термінологією, розробляється відповідне методичне забезпечення. Власне сам COVID-19 заохочує заклади вищої освіти в Україні здійснювати інноваційні рішення за досить короткий проміжок часу та запроваджувати дистанційне навчання з використанням різних веб-сервісів, платформ, ресурсів та соціальних мереж. Автори цього дослідження ідентифікували ряд труднощів та переваг запровадженого дистанційного навчання. Перш за все, реалії нашого життя показали, що не всі заклади вищої освіти технічно підготовлені до проведення дистанційного навчання. Студенти зауважили недоліки системи через відсутність живого спілкування, повторної здачі пропущених практичних занять, збільшення завдань, брак часу на виконання завдань, виконання сімейних рутинних справ, обмежений доступ до комп'ютера, відсутність забезпечення усіх членів родини власним технічним обладнанням. Викладачі відмітили неможливість індивідуального консультування студентів, збільшення часу на листування із студентами, оскільки онлайн - курси передбачають більш детальний опис домашнього завдання ніж зазвичай в аудиторії. Однак, авторами статті зазначено, що серед позитивних аспектів використання дистанційного навчання українські викладачі та студенти за результатами опитування відмічають, що якість дистанційної освіти не поступається якості навчання віч-на-віч. Самі студенти відмічають розвиток дисципліни та самореалізації, що дає можливість отримати освіту в зручний час і зручному місці та рівний доступ до освіти, незалежно від місця проживання, стану здоров'я чи соціального статусу. Викладачі вказують на оновлену роль вчителя, що стає наставником-консультантом, який координує процес навчання, постійно вдосконалюючи власні курси та навички [6].

Наразі відбувається науково-теоретичне осмислення дистанційних форм навчання, до наукового обігу входить нова термінологія, розробляється відповідне методичне забезпечення, проходить експериментальна апробація нових дистанційних освітніх технологій. Задля пристосування до тривалої пандемії, університети потребуватимуть гнучких та надійних моделей освіти, які дозволять безперервно адаптуватися до різних етапів. COVID-19 прискорив та активізував довготривалі педагогічні тенденції, створюючи природний експеримент, в якому перевіряються та оцінюються численні інновації. Перші ознаки свідчать про те, що багато нововведень, застосованих під час пандемії, будуть корисними для студентів і після кризи [7].

На початку карантину адміністрація та відділ інформаційно-аналітичного забезпечення Вінницького націо- нального медичного університету імені М.І. Пирогова провели on-line вебінар для викладацького складу, щодо особливостей застосування і роботи додатку Microsoft Teams у дистанційному навчанні. Власне після цього, кожен викладач створив за допомогою цього додатку команди, які безпосередньо відповідали академічним групам студентів відповідного курсу та спеціальності 3 клінічної дисципліни «Внутрішня медицина» [8].

Основними видами занять за дистанційною формою навчання $є$ традиційні форми освітньої підготовки, а саме лекція, практичні заняття, семінар, лабораторні заняття, консультації та інші, що відповідають чинному законодавству [9]. Власне головними учасниками навчального процесу, який проходить за дистанційною формою навчання - $є$ студенти, викладачі та, бажано, при можливості спеціалісти інформаційних технологій або адміністратори дистанційного навчання. Принцип самостійного навчання передбачає поширення необхідного освітнього контенту для проведення практичних занять і лекцій, що студенти можуть отримати через Інтернет за допомогою різніх освітніх платфрорм для самостійного оволодіння навчальним матеріалом [10].

Важливо перед початком дистанційного курсу визначитися з кожною студентською групою, щодо методів викладання та форм контролю і процесу оцінювання. Після виконання необхідного завдання студенти обов'язково мають отримати зворотній зв'язок із своїм викладачем для обговорення. Лекційний матеріал може бути із трансляцією або пропонуватись у записаному відео-форматі, або у вигляді озвучених презентацій. Досить доцільним $є$ візуальна та звукова демонстрація матеріалу, що пропонується для вивчення [11]. Поруч із цим задля навчання в дистанційному режимі раціональним $€$ використання відеоматеріалів, які знаходяться в відкритому доступі Інтернет, клінічні рекомендації та інші навчальні матеріали провідних освітніх установ світу. Практичні навчання повинні мати можливість використання засобів симуляційного навчання. Під час практичних занять навчальної дисципліни «Внутрішня медицина» особливо для студентів медиків старших курсів навчання, дистанційне навчання слід поєднувати з можливостями т елемедицини і здійсненням консультацій, консиліумів.

Перед кожним заняттям студенти мають змогу опрацювати теоретичну частину матеріалу, яка розміщена на сайті кафедри внутрішньої медицини медичного факультету №2 Вінницького національного медичного університету імені М.І. Пирогова: лекційний матеріал, методичні розробки з тестовими завданнями та ситуаційними задачами розміщені на Google диску кафедри, доступ до якого мають студенти по відповідному посиланню. Розбір теоретичних питань відповідно тематичному плану проводиться під час відеоконференції відповідно розкладу практичних занять у додатку Microsoft Teams. Основною метою дисципліни «Внутрішня медицина» $є$ оволодіння практичними навичками. Звичайно, що дистанційне навчання не може в повній мірі забезпечити засвоєння саме практичного аспекту дисципліни. Тому практичною частиною заняття $\epsilon$ представлення до уваги студентів відповідних клінічних кейсів реальних пацієнтів у вигляді презентації у форматі Microsoft PowerPoint. Це виглядає так: викладач створює мультимедійну презентацію, в якій представлений окремий клінічний випадок реального пацієнта 3 представленням його анамнестичних даних, об'єктивного, лабораторно- 
інструментального обстеження. Відповідно студентам пропонується самостійно виставити діагноз по конкретному клінічному випадку, після цього призначити відповідне лікування. Саме в такий спосіб, студент має можливість застосувати теоретичні знання в конкретному клінічному випадку. Взаємодія студентів і викладача в системі дистанційного навчання відбувається через чат-спілкування в додатку платфрорми Microsoft Teams. Таким чином студенти мають можливість проявити свою творчість та отримати додаткові бали до загальної оцінки, шляхом оволодіння матеріалом самостійно, при чому мають можливість створити та презентувати увазі власні презентації.

Незважаючи на цілий ряд позитивних характеристик, дистанційне навчання має свої складнощі. Саме від викладача вимагається кризове реагування на випадок втрат зв'язку або перебоїв у трансляції навчальних матеріалів, слід не розгублюватись та завжди бути готовим імпровізувати. Слід не забувати про самовладання, в ситуаціях, коли в роботу викладача і студентів втручається нестабільний Інтернет - зв'язок чи раптово виникають труднощі із веб - камерою, робота в активному режимі якої протягом всієї тривалості заняття - $€$ обов'язковою вимогою якісного навчання у вищому медичному закладі освіти. Окрім того, частина студентів зауважує складнощі у вигляді одночасного залучення товаришів по кімнаті у гуртожитках до своїх занять. Власне і в даній ситуації комунікація викладача і студентів, здійснювана у чатах додатків, соцмережах, електронною поштою робить нас ближчими один до одного і дає можливість отримати вкрай важливий зворотній зв'язок.

Однак, однією із важливих проблем використання дистанційного навчання $€$ забезпечення контролю клінічного досвіду. Навчання на кафедрах терапевтичного профрілю вимагає щоденного практичного вдосконалення і засвоєння мануальних навичок у ліжка хворого, лікувально - маніпуляційних кабінетах, клінічних розборах, в безпосередньому контакті з пацієнтом. Це безумовно вимагає традиційного очного контакту і співпраці з викладачем. Саме тому, дистанційне навчання при викладанні дисципліни «Внутрішня медицина» у вищому медичному закладі освіти, як комплаєнс сучасних освітніх технологій у системі вищої медичної освіти має постійно вдосконалюватись, залучаючи при цьому використання сучасних освітніх платформ, якісного методичного наповнення вебресурсів та запровадження уніфікованої системи контролю за якістю дистанційного навчання.

\section{Висновки}

Дистанційне навчання в світлі інформаційних технологій сьогодення має здатність різнопланово впливати на студента, даючи змогу більш широко оволодіти аспектами навчального матеріалу, ніж в процесі спілкування з викладачем, виробляє вміння працювати з інформацією, сприяє прийняттю правильних рішень, розвиває комунікабельні здібності. На сучасному етапі розвитку вищої медичної освіти присутня тенденція до використання принципово нових інтегрованих технологій освітньої діяльності, які дають змогу викладачам ефективно керувати процесом навчання. Важливим для студентів, здобувачів вищої медичної освіти на старших курсах при вивченні клінічних дисциплін, поєднувати навчання із застосуванням інформаційних технологій в процесі дистанційного навчання та класичного аудиторного навчання. Це дасть змогу оптимізувати та поєднати отримані теоретичні знання, практику та реальні клінічні навички для досягнення єдиної мети - підготовки вищим медичним закладом конкурентоспроможного досвідченого фрахівця медичної сфери діяльності.

Як форма освітнього процесу, дистанційне навчання має великі перспективи, особливо в умовах пандемії. Перший наш досвід проведення навчального процесу у формі дистанційного навчання продемонстрував його переваги у порівнянні з традиційними формами навчання, в першу чергу, звичайно в інформаційному плані. Присутність зручного часу серед студентів і можливість отримувати знання навіть за місцем проживання обумовили значно меншу відсутність пропущених занять студентами.

Таким чином, можна відзначити, що дистанційні технології навчання досить активно інтегруються в навчальний процес кафедри внутрішньої медицини медичного фракультету №2 Вінницького національного медичного університету імені М.І. Пирогова опановуючи навчальну дисципліну «Внутрішня медицина». У той же час, це можна назвати новим кроком у розвитку професійної майстерності працівників вищого медичного навчального закладу та причетності до реформування освітньої галузі у реаліях сучасності.

\section{Література}

1. Мисловська С.К. Підготовка студентів медичних ВНЗ до використання інформаційних технологій у професійній діяльності. Наукові записки Вінницького державного педагогічного університету імені Михайла Коцюбинського. Серія: Педагогіка і психологія 2015; 43:261-265.

2. Dhawan S. Online Learning: A Panacea in the Time of COVID-19 Crisis. 2020; 49(1):5-22. doi: $10.1177 / 0047239520934018$.

3. Вірстюк Н.Г., Оринчак М.А., Човганюк О.С., Гаман І.О. та ін. Дистанційне навчання з дисциплін внутрішня медицина для студентів медиків в умовах пандемії COVID-19. Матеріали конференції. Актуальні питання підвищення якості освітнього процесу. Тернопіль. 18 вересня, 2020:6.

4. Taylor D, Grant J, Hamdy H, Grant L, et al. Transformation to learning from a distance. MedEdPublish. 2020; 9(1):76. doi: 10.15694/mep.2020.000076.1.

5. Hamdy H. Medical College of the future: from informative to transformative. Med Teach. 2018; 40 (10):986-989. doi: 10.1080/0142159X.2018.1498628.

6. Berezhna S, Procopenko I. Higher Education Institutions in Ukraine during the Coronavirus, or COVID-19, Outbreak: New Challenges vs New Opportunities. Revista Romaneasca pentru Educatie Multidimensionala. 2020; 12(Is.1 Sup2):130-135. doi:10.18662/rrem/12.1sup2/256

7. Brammer S, Clark T. COVID - 19 and Management Education: Reflections on Challenges, Opportunities, and Potential Futures. British Journal of Management. 2020; 31(3):453-456. doi:10.1111/1467-8551.12425

8. Гончаренко О.М. Сучасні інформаційні технологій, як одна із складових дистанційного навчання в умовах пандемії COVID - 19. Medical University of Lublin. Scientific and pedagogic internship. Ways of improving the training of future professional medical and pharmaceutical specialists in Ukraine and EU Countries. Lublin, Republic of Poland. November 16 December 28, 2020:42-45.

9. Волосовець О.П., Виговська О.В., Кривопустов С.П. Дистанційне навчання як інфоомативно - комунікативна технологія додипломної підготовки лікарів з педіатрії в умовах сучасних викликів. Медична освіта. 2020; 3:9-12. doi: 10.11603/me.2414-5998.2020.3.11435.

10. Distance Education. - Access mode: https://www. tandfonline.com/toc/cdie20/current.

11. Skochelak SE, Stack SJ. Creating the medical schools of the future. Academic Medicine. 2017; 92(1):16-19. doi: 10.1097/ACM.0000000000001160.

Матеріал надійшов до редакції 24.02.2021 